Article

\title{
Cadmium Addition Effects on Anaerobic Digestion with Elevated Temperatures
}

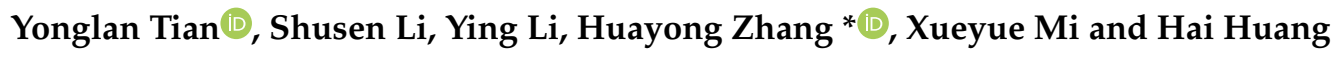 \\ Research Center for Engineering Ecology and Nonlinear Science, North China Electric Power University, \\ Beijing 102206, China; yonglantian@ncepu.edu.cn (Y.T.); $1172211079 @$ ncepu.edu.cn (S.L.); \\ 1172209043@ncepu.edu.cn (Y.L.); 1120160169@mail.nankai.edu.cn (X.M.); huanghai@ncepu.edu.cn (H.H.) \\ * Correspondence: rceens@ncepu.edu.cn; Tel.: +86-010-617-739-36
}

Received: 7 May 2019; Accepted: 18 June 2019; Published: 20 June 2019

\begin{abstract}
Anaerobic fermentation with biogas as an energy source is influenced by the presence of heavy metals. However, the availability of the heavy metals is dependent on the digestion temperature. In this study, the impacts of $\mathrm{Cd}$ on the characteristics of biogas, substrate biodegradation, and enzyme activity during anaerobic co-digestion were investigated under varying digestion temperatures. The results showed that $1 \mathrm{mg} / \mathrm{L}$ initial Cd concentration improved cumulative biogas yields by $404.96 \%, 16.93 \%$, and $5.56 \%$ at $55^{\circ} \mathrm{C}, 45^{\circ} \mathrm{C}$, and $35{ }^{\circ} \mathrm{C}$, respectively. In contrast, at low temperatures $\left(25{ }^{\circ} \mathrm{C}\right)$, the yield decreased by $0.77 \%$. In the $55^{\circ} \mathrm{C}$ group, $\mathrm{Cd}$ addition improved the activity of cellulase $(p<0.05)$ and coenzyme $\mathrm{F}_{420}(p<0.01)$. The total chemical oxygen demand (COD) during the peak period and the transformation of hydrolytic organic components into volatile fatty acids (VFAs) influenced the $\mathrm{CH}_{4}$ and biogas yields. There were no significant differences in cellulase, dehydrogenase, and coenzyme $\mathrm{F}_{420}$ activities with or without $\mathrm{Cd}$ addition when the digestion temperature was $45^{\circ} \mathrm{C}, 35^{\circ} \mathrm{C}$, and $25^{\circ} \mathrm{C}$. Therefore, thermophilic digestion is recommended for the efficient degradation of $\mathrm{Cd}$-contaminated biowaste. Moreover, the impact of metals on the performance of anaerobic digestion should be considered together with temperature conditions in future research and practice.
\end{abstract}

Keywords: cadmium; $\mathrm{CH}_{4}$ production; substrate biodegradation; enzyme

\section{Introduction}

Lignocellulosic biomass wastes, which are being generated in large amounts annually, can be used as an energy resource by sustainable technologies, such as anaerobic digestion [1-3]. The digestion microorganism in the reactors requires a trace amount of certain metals for optimal growth and performance [4]. In the past decades, the impacts of cadmium (Cd) on anaerobic digestion received great attention since it is a metal of major environmental and human concern [5-8].

Previous studies reported that the toxicity of $\mathrm{Cd}$ influenced the efficiency and amount of $\mathrm{CH}_{4}$ formation [9-12]. However, only few studies showed that the biogas yields during anaerobic digestion of bioenergy crops were enhanced by $\mathrm{Cd}$ contamination at a certain concentration range $[5,8,13,14]$. Cd concentrations of $2.00 \pm 0.44,39.80 \pm 1.25$, and $6.37 \pm 0.15 \mathrm{mg} \mathrm{Cd} / \mathrm{kg}$ biomass in the shoot of canola, oat, and wheat improved the biogas yields by $59.37 \%, 79.23 \%$, and $11.34 \%$ compared to the control group under thermophilic conditions $\left(55.0 \pm 1.0^{\circ} \mathrm{C}\right)$ [8]. A study on biogas production with maize contaminated with $\mathrm{Cd}$ as feedstocks (the final $\mathrm{Cd}$ concentration of residues achieved $5.34 \mathrm{mg} / \mathrm{kg}$ ) found no inhibitory effects during the anaerobic digestion process $\left(42^{\circ} \mathrm{C}\right)$ [7]. An activating effect of $\mathrm{Cd}^{2+}$ was found on methanogenesis in the marine archaeon Methanosarcina acetivorans [15]. With acetate as substrate, $\mathrm{Cd}^{2+}$ slightly increased both the growth and methane rate synthesis [15]. In spite of this, 
there is still lack of information about the role of $\mathrm{Cd}$ in biodegradation, particularly on the modification of the methanogenic pathway.

The concentration of the available $\mathrm{Cd}$ in the reactor is greatly influenced by temperature changes. Under thermophilic conditions $\left(55.0 \pm 1.0^{\circ} \mathrm{C}\right), \mathrm{Cd}$ concentrations less than $1.0 \mathrm{mg} / \mathrm{L}$ were shown to be non-inhibitory to the anaerobic digestion process [14]. However, to the best of our knowledge, most of the previous research on the impacts of temperature was carried out without considering the presence of heavy metals in the reactors.

The aim of this study was to examine the effect of elevated temperatures combined with the addition of $\mathrm{Cd}$ on the anaerobic digestion of lignocellulosic biomass. The impacts of $\mathrm{Cd}$ on the biogas properties, substrate biodegradation, and enzyme activity were investigated by comparing with a control that had no Cd added. Data from this study demonstrate the impact of temperatures on the performance and biodegradability of anaerobic fermentation and provide information for biogas production practice from metal-contaminated lignocellulosic biomass.

\section{Materials and Methods}

\subsection{Experimental Materials}

A corn stover, a representation of lignocellulosic biomass, collected from farmland in Shandong Province, China was used as the feedstock. Prior to grinding into powder and passing through a 10 -mesh sieve, the corn stover was air-dried. The stover was then pretreated with $6 \%$ phosphoric acid for $24 \mathrm{~h}$ at room temperature to destroy the lignocellulosic structure and enhance fermentation efficiency. After pretreatment, the corn stover was washed with deionized water 5-8 times. Fresh cow dung collected from the Yanqing base, Beijing Dairy Cattle Center was used as an inoculum. It was stored at $4.0^{\circ} \mathrm{C}$. The total solid (TS) of the raw cow dung was $15.44 \pm 1.13 \%$ dry weight, and the volatile solid (VS) was $85.95 \pm 2.18 \%$ of TS. No extra inoculum was used to start the experiment. The $\mathrm{Cd}$ contents in the corn stover and cow dung were lower than the limit of detection.

\subsection{Anaerobic Fermentation Experiment Set-Up}

The experiments were performed in the anaerobic reactors (working volume of $20 \mathrm{~L}$, total volume of 30 L, YGF 300/30, Shanghai Yangge Biological Engineering Equipment Co., Ltd., Shanghai, China) for 16 days at $55^{\circ} \mathrm{C}, 45^{\circ} \mathrm{C}, 35^{\circ} \mathrm{C}$, and $25^{\circ} \mathrm{C}\left( \pm 1.0^{\circ} \mathrm{C}\right.$, automatically controlled $)$. Acid-pretreated corn stover ( $0.8 \mathrm{~kg}$ dry weight) was mixed with cow dung ( $0.8 \mathrm{~kg}$ dry weight, also worked as inoculum) as feedstocks. TS of the substrate in the reactors was set at $8 \%$ by adding distilled water. At the beginning of fermentation, $\mathrm{CdCl}_{2}$ solution was then added into the reactors to achieve a final concentration of $1 \mathrm{mg} / \mathrm{L}$ based on a previous study [14]. The reactors were purged with $\mathrm{N}_{2}$ gas for $5 \mathrm{~min}$ to remove the oxygen.

\subsection{Measurements}

Biogas yield was automatically measured at 9:00 a.m. each day using a gas flowmeter (MGC-1 V3.1 PMMA, Dr Ing. Ritter Apparatebau Gmbh \& Co. Kg. Germany) connected to the reactor. Solid, liquid, and gas samples were collected every three days at 9:00 a.m. The TS, volatile solids (VS), chemical oxygen demand (COD), and cellulose, cellulase, and coenzyme $\mathrm{F}_{420}$ activities were measured using methods previously reported [16-19]. Briefly, TS was determined by weighing the samples after drying at $105^{\circ} \mathrm{C}$ for $24 \mathrm{~h}$, while VS was determined after treating the samples in a muffle furnace at $550^{\circ} \mathrm{C}$ for $1 \mathrm{~h}$. The COD in the supernatant was obtained using the potassium dichromate method after sample centrifugation at $5000 \mathrm{rpm}$ for $10 \mathrm{~min}$. Cellulose was determined after the removal of lipids and treatment using nitric acid and ethanol [19]. Cellulase and coenzyme $\mathrm{F}_{420}$ activities in the supernatant were determined according to the standard method after centrifugation at $4000 \mathrm{rpm}$ for $5 \mathrm{~min}$ [20]. Samples for volatile fatty acids (VFAs) analysis were passed through a $0.45-\mu \mathrm{m}$ nitrocellulose membrane filter and frozen prior to analysis. VFA concentrations were determined by a 
gas chromatograph (GC-2014, Shimadzu Co., Japan) with a flame ionization detector (FID). VFA was expressed as $\mathrm{mg} / \mathrm{L}$ of individual species ( $\mathrm{C} 2-\mathrm{C} 5$ fatty acids). $\mathrm{CH}_{4}$ content in biogas was measured by a gas chromatograph (GC-2014C, Shimadzu Co. Japan) equipped with a GDX-401 column and $\mathrm{H}_{2}$ as the carrier gas. Detection was performed with a thermal conductivity detector (TCD).

\subsection{Data Analysis}

The data in the study were the average of three repeats. Error bars represent the standard errors of the mean $(\mathrm{SEM})=\mathrm{SD} / \sqrt{n}$, where $\mathrm{SD}$ is the standard deviation. One-way analysis of variance (one-way ANOVA), at $0.05(* p<0.05)$ and $0.01\left({ }^{* *} p<0.01\right)$ levels of significance, was performed using Statistical Package for the Social Sciences software (IBM SPSS Statistics 21, Chicago, IL, USA).

\section{Results and Discussion}

\subsection{Fate of $C d$ during the Digestion Process}

The fate of $\mathrm{Cd}$ in the reactor was important for the deposition of residues, as $\mathrm{Cd}$ is both toxic and a probable carcinogen. Figure 1 shows the $\mathrm{Cd}$ concentrations in the digestion liquor during the digestion process. In the $55^{\circ} \mathrm{C}$ group, the $\mathrm{Cd}$ concentration on the first day was $0.18 \mathrm{mg} / \mathrm{L}$, which was much lower than the initial $\mathrm{Cd}$ concentration. This suggests that most of the $\mathrm{Cd}$ added was removed from the digestion liquor. However, heavy metals may be adsorbed onto the solid fraction (i.e., the biomass or inert particulate matter) [21]. The adsorption of $\mathrm{Cd}^{2+}$ was favored by increasing the temperature, since $\mathrm{Cd}^{2+}$ adsorption is an endothermic process [22]. Therefore, the low $\mathrm{Cd}$ concentrations observed in the $55^{\circ} \mathrm{C}$ group could be attributed to $\mathrm{Cd}$ precipitation and adsorption. After the seventh day, the $\mathrm{Cd}$ concentrations increased to $0.27 \mathrm{mg} / \mathrm{L}$ and finally reached $0.31 \mathrm{mg} / \mathrm{L}$ at the end of the experiment. This increase in the $\mathrm{Cd}$ concentrations was likely due to the degradation or desorption of the substrate. The corresponding reduction in the daily biogas yields indicated Cd's toxicity to biogas production.

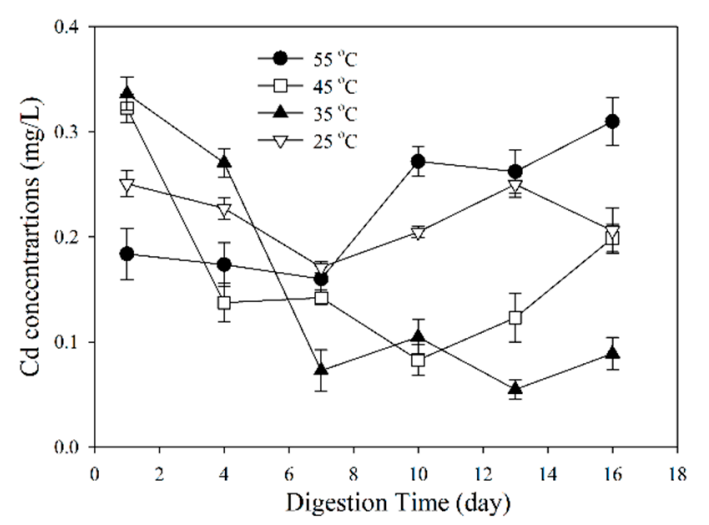

Figure 1. Cd concentrations in the digestion liquor $(\mathrm{mg} / \mathrm{L})$ during the anaerobic digestion.

The $\mathrm{Cd}$ concentrations in the 45 and $35^{\circ} \mathrm{C}$ groups were higher than that in the $55^{\circ} \mathrm{C}$ group on the first day of digestion, followed by the $25^{\circ} \mathrm{C}$ group. At the end of the experiment, it was found that the $\mathrm{Cd}$ concentrations were in the order of $55^{\circ} \mathrm{C}>25^{\circ} \mathrm{C}>35^{\circ} \mathrm{C}>45^{\circ} \mathrm{C}$, which was opposite to the order on the first day of digestion. Therefore, under high-temperature conditions $\left(55^{\circ} \mathrm{C}\right)$, more $\mathrm{Cd}$ was removed from the liquor at the beginning of digestion, which was beneficial for the start-up stage, as well as high biogas yields during the digestion process. However, at the end of digestion under high-temperature conditions $\left(55^{\circ} \mathrm{C}\right)$, more $\mathrm{Cd}$ was released to the liquor, probably due to enhanced substrate degradation in these conditions. 


\subsection{Biogas Properties under Different Temperatures}

Figure 2 shows the impact of $\mathrm{Cd}$ addition on the cumulative biogas yields under different digestion temperatures. When the temperatures were $55^{\circ} \mathrm{C}, 45^{\circ} \mathrm{C}$, and $35^{\circ} \mathrm{C}$, the $\mathrm{Cd}$-added groups obtained higher biogas yields than the control group (no Cd-added) by $404.96 \%, 16.93 \%$, and $5.56 \%$, respectively. Thus, $\mathrm{Cd}$ addition enhanced the biogas production within the temperature range. When the temperature further decreased to $25^{\circ} \mathrm{C}$, biogas yields in the $\mathrm{Cd}$-added group were lower than in the control group $(-0.77 \%)$, indicating that $\mathrm{Cd}$ had an inhibitory effect on biogas production. According to the logistic fitting results, the theoretical maximum cumulative biogas yields showed the same tendency with the experimental results. Similar to the results of cumulative biogas yields, the stimulatory effect of $\mathrm{Cd}$ on daily biogas yields was remarkable when the digestion temperature was $55^{\circ} \mathrm{C}$ (Figure 3 ).

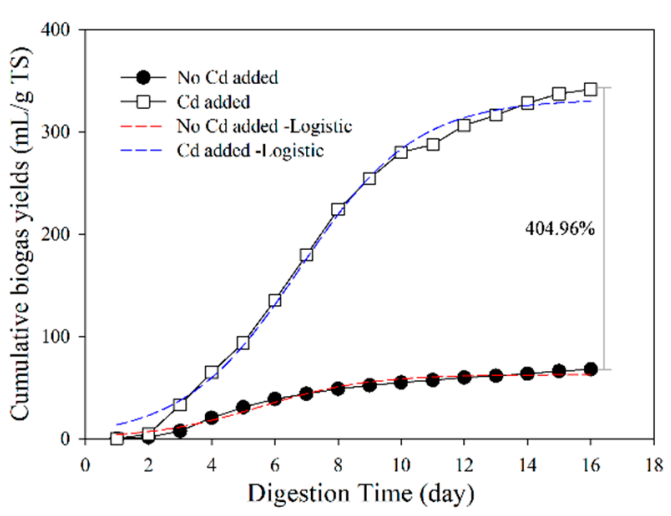

(a)

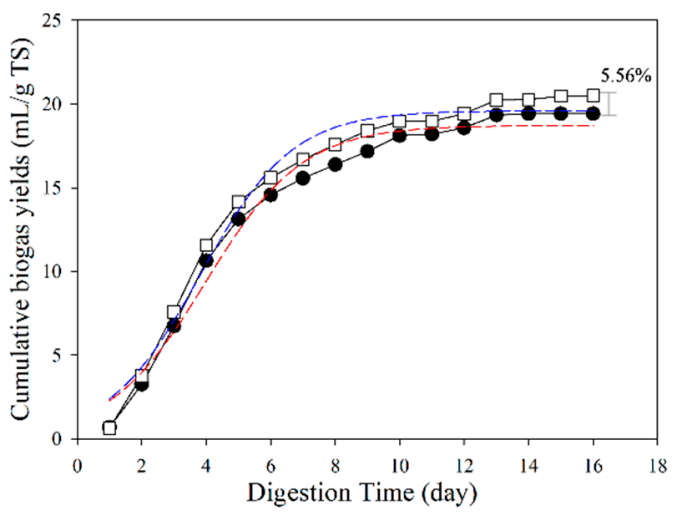

(c)

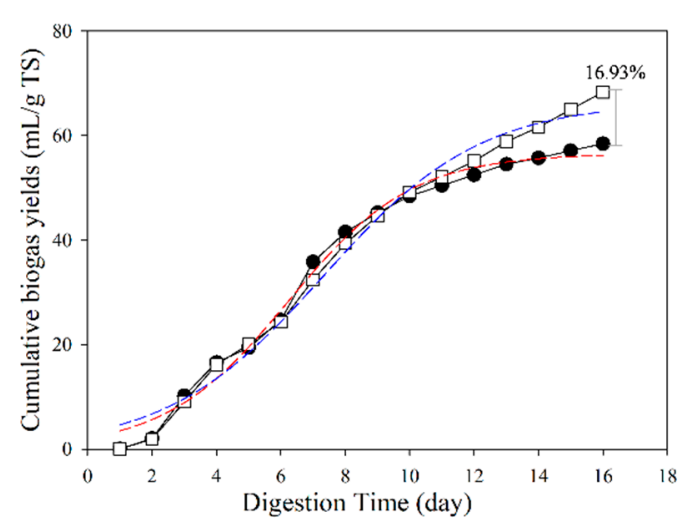

(b)

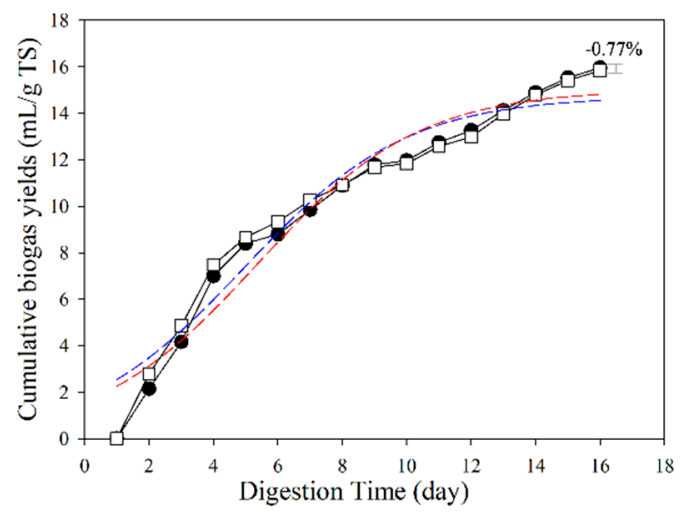

(d)

Figure 2. Cumulative biogas yields and logistic fitting results under $\mathrm{Cd}$ stress with digestion temperatures of $55^{\circ} \mathrm{C}(\mathbf{a}), 45^{\circ} \mathrm{C}(\mathbf{b}), 35^{\circ} \mathrm{C}(\mathbf{c})$, and $25^{\circ} \mathrm{C}(\mathbf{d})$. 


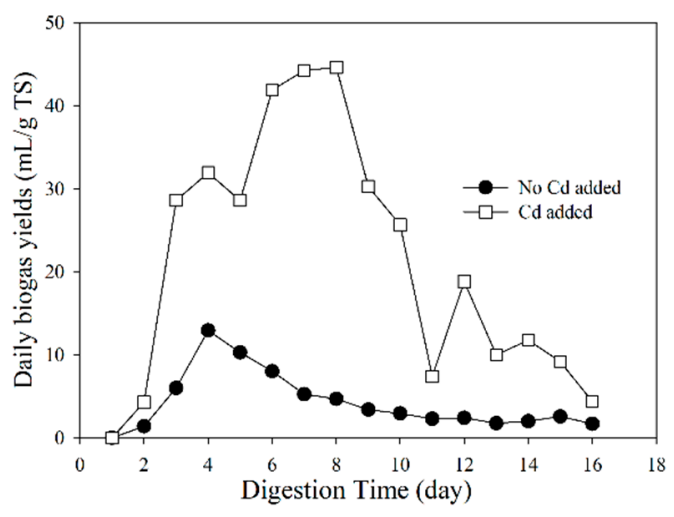

(a)

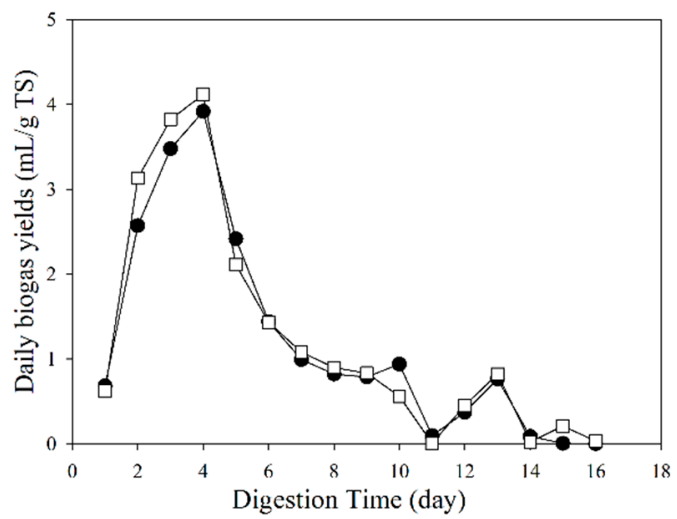

(c)

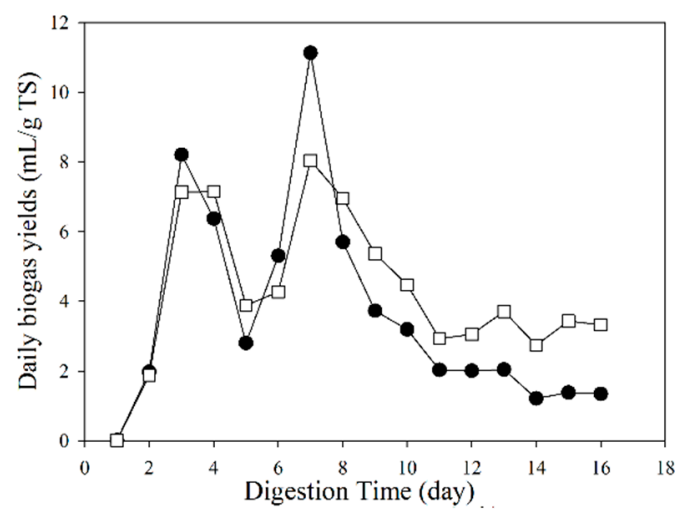

(b)

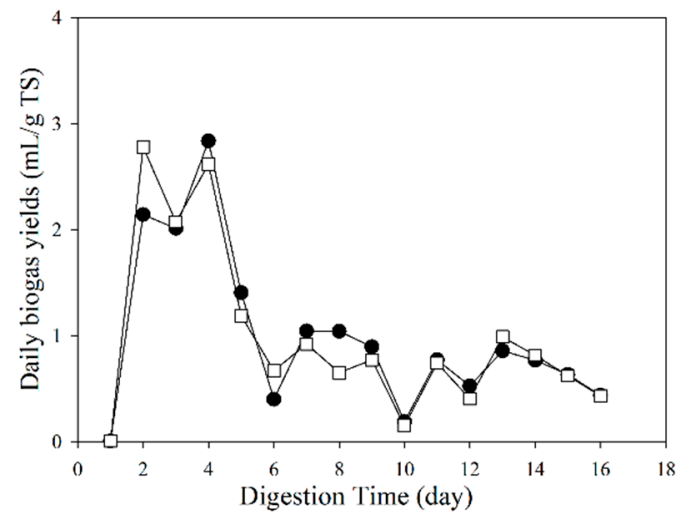

(d)

Figure 3. Daily biogas yields under $\mathrm{Cd}$ stress with digestion temperatures of $55^{\circ} \mathrm{C}(\mathbf{a}), 45^{\circ} \mathrm{C}(\mathbf{b}), 35^{\circ} \mathrm{C}$ (c), and $25^{\circ} \mathrm{C}$ (d).

The stimulatory effects of $\mathrm{Cd}$ were also found in anaerobic digestion when other crops were used as feedstocks $[8,14]$. A previous study found that there was no inhibitory effect on biogas production when $\mathrm{Cd}$ less than $1 \mathrm{mg} / \mathrm{L}$ was present in a thermophilic reactor [14]. In the present study, the available $\mathrm{Cd}$ concentrations in the reactor during digestion were lower than $1 \mathrm{mg} / \mathrm{L}$ as there were $\mathrm{Cd}$ losses due to precipitation, sorption, and formation of complexes [21]. Despite the low $\mathrm{Cd}$ concentrations in the $25^{\circ} \mathrm{C}$ group, an inhibitory effect on biogas production was observed. A previous study found that low temperatures reduced $\mathrm{CH}_{4}$ production when swine manure was used as the substrate [23]. These results were contrary to a previous study $\left(25-27^{\circ} \mathrm{C}\right)$ on acetateand methanol-grown Methanosarcina acetivorans C2A strain cells in which Cd showed a significant stimulatory effect on the $\mathrm{CH}_{4}$ production [15]. Therefore, temperature variations should be taken into account when establishing the threshold or optimal range of $\mathrm{Cd}$ concentrations for biogas production.

The $\mathrm{CH}_{4}$ contents in the biogas varied with temperatures in the presence of $\mathrm{Cd}$ as shown in Figure S1 (Supplementary Materials). Trends in $\mathrm{CH}_{4}$ contents in the $35^{\circ} \mathrm{C}$ and $25^{\circ} \mathrm{C}$ groups were not characterized fully because the biogas yields were too low for collection by the gas bag. Overall, when temperature increased, the $\mathrm{CH}_{4}$ contents increased in both $\mathrm{Cd}$-added and control groups. $\mathrm{CH}_{4}$ contents reached a plateau after the fourth day in the $55^{\circ} \mathrm{C}$ group, while they continued increasing at lower temperatures. The results indicated that elevated temperatures accelerated the start-up of fermentation. On the other hand, $\mathrm{Cd}$ addition improved the $\mathrm{CH}_{4}$ contents by approximately $6 \%$ after the fourth day in the $55^{\circ} \mathrm{C}$ group. The impact of $\mathrm{Cd}$ on biogas compositions in the other three temperature groups was not significant. Therefore, thermophilic digestion $\left(55^{\circ} \mathrm{C}\right)$ promoted the $\mathrm{CH}_{4}$ production in the presence of $\mathrm{Cd}$. In contrast, low temperature hindered the production of $\mathrm{CH}_{4}$, which agreed with a previous study that used swine manure as a substrate [23]. 


\subsection{Substrate Biodegradation}

\subsubsection{Responses of VFAs}

The VFA compositions (as mg/L acetic acid) are presented in Figure 4. The variation of VFAs was influenced greatly by both $\mathrm{Cd}$ addition and digestion temperatures. The total VFA concentrations in the Cd-added $55^{\circ} \mathrm{C}$ group increased from the first to the fourth day (Figure 4a). During this period, acidogens were probably active, leading to the formation of VFAs and other organic products as a result of acidogenic reactions that proceed after hydrolysis [24]. The total VFA concentrations remained high between the fourth and seventh day (i.e., peak biogas-producing period) and decreased rapidly afterward. In general, the VFA concentration in the Cd-added group varied in similar tendency with the daily biogas yields. Comparing the VFA concentrations and biogas yields under different digestion temperature revealed that the amount of the total VFA concentrations did not dominate the biogas production.

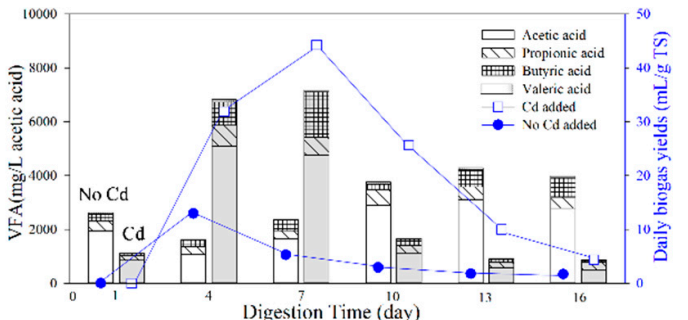

(a)

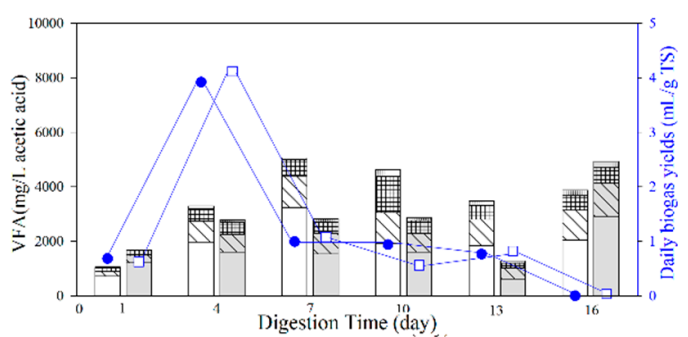

(c)

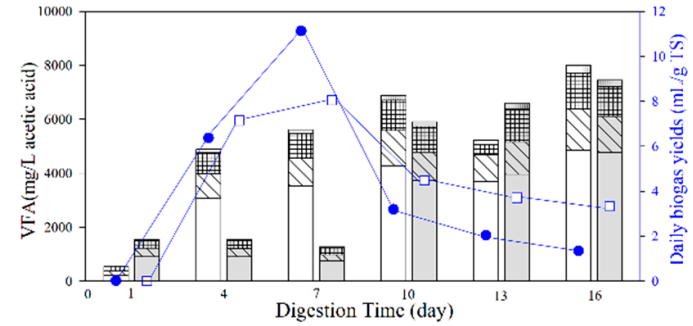

(b)

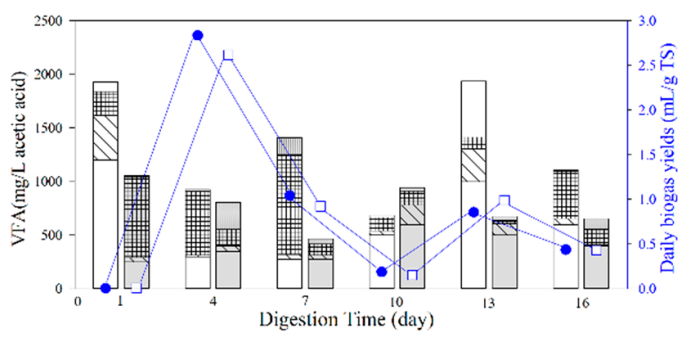

(d)

Figure 4. Volatile fatty acid (VFA) concentrations (as $\mathrm{mg} / \mathrm{L}$ acetic acid) in the liquid phase with (right gray column) and without (left white column) $\mathrm{Cd}$ stress with digestion temperatures of $55{ }^{\circ} \mathrm{C}(\mathbf{a}), 45^{\circ} \mathrm{C}$ (b), $35^{\circ} \mathrm{C}$ (c), and $25^{\circ} \mathrm{C}$ (d). The compositions of VFA are shown by stacked bars with the order of acetic acid (blank), propionic acid (coarse), butyric acid (grid), and valeric acid (dotted) from bottom.

Acetic acid was the main component of the VFA, followed by propionic acid $\approx$ butyric acid $>$ valeric acid in the $55^{\circ} \mathrm{C}, 45^{\circ} \mathrm{C}$, and $35^{\circ} \mathrm{C}$ groups. When the digestion temperature was $25^{\circ} \mathrm{C}$, the percentages of butyric acid and valeric acid increased at various time intervals in the no Cd-added group, as well as the first day of the Cd-added group. The concentrations of butyric acid were even higher than the concentrations of acetic acid sometimes. Therefore, low temperature was not beneficial for the generation of acetic acid or transforming high VFAs (butyric acid and valeric acid) into low VFAs (acetic acid), especially in the no Cd-added group. It was, thus, proposed that the reaction rate of generating acetate from glucose (Equation (1)) or acetogenesis from butyric acid (Equation (2)) was limited [25]. The reaction of Equation (2) was probably limited due to the high free energy yield $(48 \mathrm{KJ} / \mathrm{mol})$ for the transformation of butyrate to acetate [25]. Cd addition was unlikely to weaken the limitation.

$$
\begin{gathered}
\mathrm{C}_{6} \mathrm{H}_{12} \mathrm{O}_{6}+\mathrm{H}_{2} \mathrm{O} \rightarrow 2 \mathrm{CH}_{3} \mathrm{COOH}+2 \mathrm{CO}_{2}+4 \mathrm{H}_{2} . \\
\mathrm{CH}_{3} \mathrm{CH}_{2} \mathrm{CH}_{2} \mathrm{COOH}+2 \mathrm{H}_{2} \mathrm{O} \rightarrow 2 \mathrm{CH}_{3} \mathrm{COO}^{-}+2 \mathrm{H}^{+}+2 \mathrm{H}_{2} .
\end{gathered}
$$


Upon comparison of the VFAs in the Cd-added group and no Cd-added group, it was found that the impact of $\mathrm{Cd}$ addition on the acetic acid, propionic acid, and butyric acid was similar in the $35^{\circ} \mathrm{C}$ group, while the impact on the valeric acid was different (Figure S2, Supplementary Materials). The low acetic acid in the Cd-added group accounted for the results of biogas yields when the Cd-added group obtained lower biogas yields than the no $\mathrm{Cd}$-added group when the digestion temperature was $25^{\circ} \mathrm{C}$. In the study of the effect of $\mathrm{Cd}$ in mesophilic $\left(37^{\circ} \mathrm{C}\right)$ anaerobic acidogenesis of a simulated dairy waste, it was found that a low dosage of $C d(5$ to $20 \mathrm{mg} / \mathrm{L})$ resulted in a decrease of both acetate and butyrate concentrations and a significant accumulation of propionate [26]. The present study indicated that the accumulation or decline of VFAs should be analyzed according to the digestion stages and temperatures.

\subsubsection{COD}

The hydrolytic products in the digestion liquor could be represented by COD. In the $55{ }^{\circ} \mathrm{C}$ group, COD concentration in both the $\mathrm{Cd}$-added and no $\mathrm{Cd}$-added group showed similar trends; there was an initial increase in COD concentration followed by a gradual decrease (Figure 5). The average COD during the entire digestion process in the $\mathrm{Cd}$-added and no $\mathrm{Cd}$-added group was $9651.83 \pm 1374.29$ and $10,172.01 \pm 1138.17 \mathrm{mg} / \mathrm{L}$, respectively. Higher COD peak period was observed in the Cd-added group than the no Cd-added group, and the biogas yield was also higher in the former group. Thus, $\mathrm{Cd}$ addition enhances the biogas production by increasing the total COD during the peak period and, more importantly, by transferring the hydrolytic organic components into VFAs (Figure S2, Supplementary Materials).

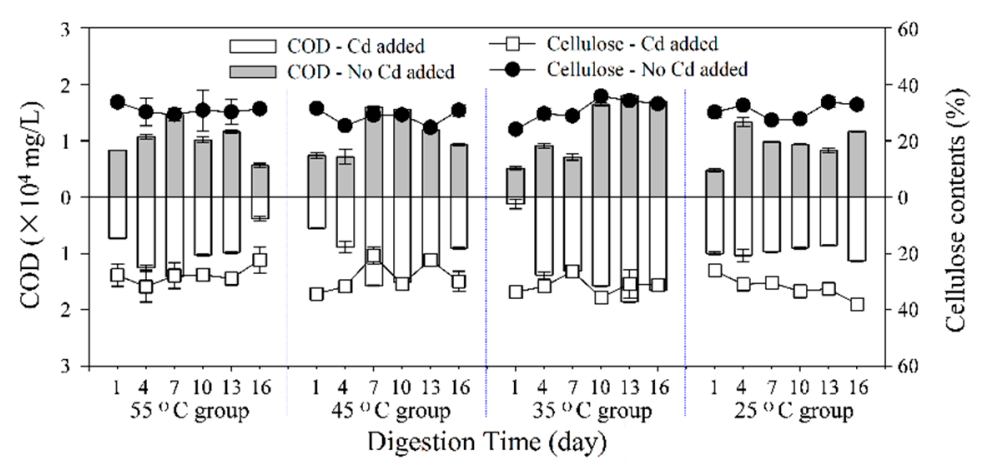

Figure 5. Chemical oxygen demand (COD) of the no Cd-added group and Cd-added group with digestion temperatures of $55{ }^{\circ} \mathrm{C}, 45^{\circ} \mathrm{C}, 35^{\circ} \mathrm{C}$, and $25^{\circ} \mathrm{C}$.

By comparing the COD concentrations of different temperature groups, it was found that high COD concentrations did not induce high biogas yields $[18,27,28]$. In fact, the improved generation of VFAs from hydrolytic products and the formation of acetic acid under thermophilic conditions increased biogas yields. Under thermophilic conditions, substrates in the reactors were more accessible and biogas yields were improved compared to mesophilic processes.

\subsubsection{Degradation of Cellulose}

The cellulose contents in the solid residues are shown in Figure 5. The average cellulose contents in the no Cd-added groups were $30.92 \%, 28.43 \%, 30.92 \%$, and $30.70 \%$ for $55{ }^{\circ} \mathrm{C}, 45^{\circ} \mathrm{C}, 35{ }^{\circ} \mathrm{C}$, and $25{ }^{\circ} \mathrm{C}$ groups, respectively, and were $27.68 \%, 28.30 \%, 31.53 \%$, and $31.90 \%$ in the $\mathrm{Cd}$-added groups. There were no significant differences between the $\mathrm{Cd}$-added group and the no $\mathrm{Cd}$-added group at all investigated temperatures (one-way ANOVA, $p>0.05$ ).

In the $55^{\circ} \mathrm{C}$ group, the decrease of cellulose in the no Cd-added group from the first to the seventh day was accompanied by an increase in COD. This suggested that the organic components in the liquor likely originated from the cellulose of the feedstock. After the seventh day, the cellulose contents 
were stable while the COD decreased. The hydrolysis of cellulose was, thus, less efficient during this period. The generation of VFAs consumed the hydrolytic products and induced the decrease in COD. In the Cd-added group, the variation of cellulose was similar with that observed in COD. The organic components in the liquor were probably from non-cellulose compositions. On the other hand, the hydrolytic products were efficiently transferred into the VFAs and eventually $\mathrm{CH}_{4}$.

In the $45^{\circ} \mathrm{C}$ group, in the presence of $\mathrm{Cd}$, the degradation of cellulose resulted in the increase of COD in the first seven days. Afterward, COD was decreased due to the increase of VFAs, and the degradation of cellulose varied with the digestion progressing. In the $35{ }^{\circ} \mathrm{C}$ group, the organic components in the liquor of the no $\mathrm{Cd}$-added group likely originated from non-cellulose compositions, as the COD and cellulose contents were both low in the first seven days and then increased during the later stages. In the presence of $\mathrm{Cd}$, the cellulose contents varied from $26.3 \%$ to $35.6 \%$ and did not have remarkable relationships with the variation of COD. In the $25{ }^{\circ} \mathrm{C}$ group, the cellulose contents in the $\mathrm{Cd}$-added group increased gradually with the digestion progressing, which should be attributed to the degradation of non-cellulose compositions.

\subsection{Responses of Enzyme Activity to Varied Temperatures under Cd Stress}

\subsubsection{Cellulase}

The cellulase plays an important role in the hydrolysis stage. It was related to the cellulose contents and COD concentrations in the liquid phase of substrate. The average cellulase activities in the no Cd-added groups were $44.41 \pm 4.14,68.14 \pm 13.64,61.11 \pm 14.74$, and $57.18 \pm 14.71 \mu \mathrm{g} /(\mathrm{mL} \cdot \mathrm{min})$ for $55^{\circ} \mathrm{C}, 45^{\circ} \mathrm{C}, 35^{\circ} \mathrm{C}$, and $25^{\circ} \mathrm{C}$ groups, respectively, and were $76.99 \pm 12.52,59.18 \pm 6.49,45.91 \pm 9.82$, and $57.87 \pm 7.13 \mu \mathrm{g} /(\mathrm{mL} \cdot \mathrm{min})$ in the $\mathrm{Cd}$-added groups (Figure 6). Therefore, in the $55^{\circ} \mathrm{C}$ group, $\mathrm{Cd}$ addition significantly improved the activity of cellulase $(p<0.05)$. There was no significant difference between the $\mathrm{Cd}$-added and no $\mathrm{Cd}$-added group when the digestion temperature was $45^{\circ} \mathrm{C}, 35^{\circ} \mathrm{C}$, and $25^{\circ} \mathrm{C}$.

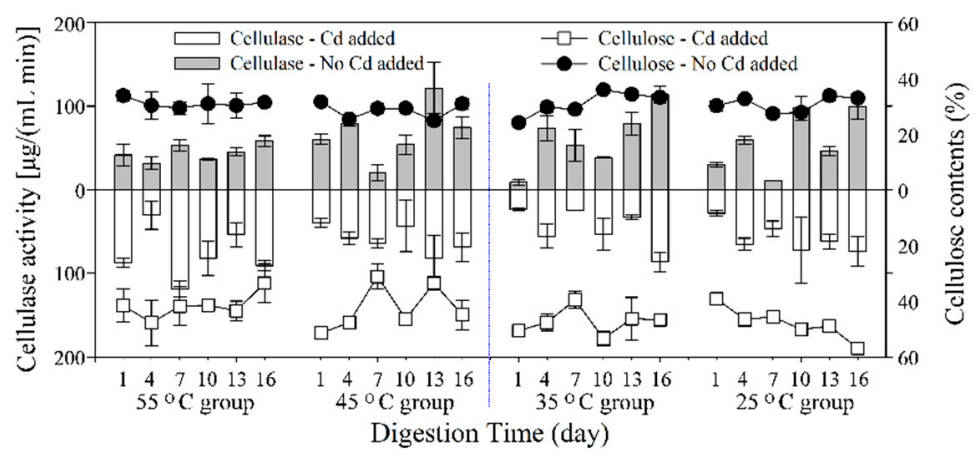

Figure 6. Cellulase activity of the no $\mathrm{Cd}$-added group and $\mathrm{Cd}$-added group with digestion temperatures of $55^{\circ} \mathrm{C}, 45^{\circ} \mathrm{C}, 35^{\circ} \mathrm{C}$, and $25^{\circ} \mathrm{C}$.

When the digestion temperature was $55^{\circ} \mathrm{C}$, in spite of higher cellulase activity in the Cd-added group, the cellulose content was not significantly decreased (Figure 5). It was attributed to the degradation of non-cellulose compositions, such as hemicellulose, which resulted in the better degradation of the feedstock and higher biogas yields (Figure 3a). In the $45{ }^{\circ} \mathrm{C}$ group, the variation of cellulase activity was opposite to the variation of cellulose contents, i.e., the increase of cellulase activity caused the corresponding degradation of cellulose. In the $35^{\circ} \mathrm{C}$ and $25{ }^{\circ} \mathrm{C}$ groups, there was no clear relationship between the variation of cellulase activity and degradation of cellulose, regardless of whether $\mathrm{Cd}$ was added or not. It seemed that the cellulose was not well degraded in the feedstock, and its percentage in the solid residue was influenced greatly by the degradation of other non-cellulose compositions. 


\subsubsection{Coenzyme $\mathrm{F}_{420}$}

Coenzyme $\mathrm{F}_{420}$ functions in the $\mathrm{H}_{2} / \mathrm{CO}_{2}$ pathway [17], which contributes to $30 \%$ of $\mathrm{CH}_{4}$ production in most systems $[29,30]$. However, the contribution of $\mathrm{H}_{2} / \mathrm{CO}_{2}$ versus acetate as metabolic precursors for methanogens may be greatly different in various anaerobic environments [30]. The average coenzyme $\mathrm{F}_{420}$ activities in the no Cd-added groups were $5.00 \pm 1.14,3.47 \pm 0.75,2.83 \pm 0.86$, and $4.42 \pm 1.00 \mu \mathrm{g} /(\mathrm{mL} \cdot \mathrm{min})$ for $55^{\circ} \mathrm{C}, 45^{\circ} \mathrm{C}, 35^{\circ} \mathrm{C}$, and $25^{\circ} \mathrm{C}$ groups, respectively, and were $11.41 \pm 2.49$, $4.11 \pm 1.08,2.99 \pm 1.12$, and $3.49 \pm 0.75 \mu \mathrm{g} /(\mathrm{mL} \cdot \mathrm{min}$ ) in the Cd-added groups (Figure 7). Therefore, in the $55{ }^{\circ} \mathrm{C}$ group, $\mathrm{Cd}$ addition significantly improved the activity of coenzyme $\mathrm{F}_{420}(p<0.01)$. There was no significant difference between the $\mathrm{Cd}$-added and no $\mathrm{Cd}$-added group when the digestion temperature was $45^{\circ} \mathrm{C}, 35^{\circ} \mathrm{C}$, and $25^{\circ} \mathrm{C}$.

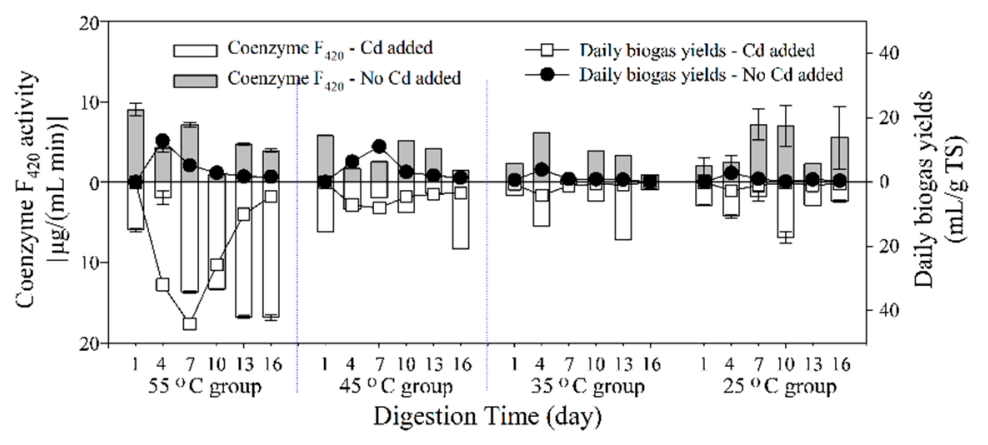

Figure 7. Coenzyme $\mathrm{F}_{420}$ activity of the no $\mathrm{Cd}$-added group and $\mathrm{Cd}$-added group with digestion temperatures of $55^{\circ} \mathrm{C}, 45^{\circ} \mathrm{C}, 35^{\circ} \mathrm{C}$, and $25^{\circ} \mathrm{C}$.

The results of coenzyme $\mathrm{F}_{420}$ activity showed that higher coenzyme $\mathrm{F}_{420}$ activities did not always result in higher biogas production. The stimulatory effect of $\mathrm{Cd}$ addition on the coenzyme $\mathrm{F}_{420}$ activity was only significant when the temperature was $55{ }^{\circ} \mathrm{C}$, and this probably accounted for the higher biogas yields. Thus, the $\mathrm{H}_{2} / \mathrm{CO}_{2}$ pathway was probably enhanced by $\mathrm{Cd}$ addition when the digestion temperature was $55^{\circ} \mathrm{C}$, which corresponded with the higher $\mathrm{CH}_{4}$ contents and the lower $\mathrm{CO}_{2}$ and $\mathrm{H}_{2}$ contents in the biogas. However, this phenomenon was not found in the other three digestion temperature conditions. At an incubation temperature of $25-27^{\circ} \mathrm{C}$, the influence of $\mathrm{Cd}$ on enzyme activities was previously examined in marine archaeon Methanosarcina acetivorans [15]. The results showed that acetate kinase activity was slightly increased $(25-30 \%)$ by $10 \mu \mathrm{M}$ total Cd, while CO dehydrogenase /acetylCoA synthase activity and carbonic anhydrase were not activated. Cd was shown to bind and activate carbonic anhydrase in vivo [31], and uncouple the methanogenic pathway by collapsing the ion gradient across the plasma membrane [15].

In the present study, the elevated temperature enhanced the activity of the cellulase and then increased the degradation of cellulose in the presence of $\mathrm{Cd}$. More organic matter was hydrolyzed and acidified into VFA compositions. A digestion temperature of $55{ }^{\circ} \mathrm{C}$ benefited the transformation of higher VFAs (such as butyrate and valeric acid) to acetic acid, thus providing enough precursors for methanogenesis. The activity of co-enzyme $\mathrm{F}_{420}$ was also stimulated, leading to the observed increase of biogas yields. More importantly, the $\mathrm{CO}_{2}$ in the biogas was utilized for $\mathrm{CH}_{4}$ production, resulting in higher $\mathrm{CH}_{4}$ yields in the thermophilic anaerobic digestion.

\section{Conclusions}

This study examined the combined effects of temperatures and $\mathrm{Cd}$ addition on anaerobic digestion. The addition of $1 \mathrm{mg} / \mathrm{L}$ initial $\mathrm{Cd}$ concentration into the anaerobic digestion improved the biogas yields of the $55^{\circ} \mathrm{C}$ group, followed by $45^{\circ} \mathrm{C}$ and $35^{\circ} \mathrm{C}$ groups, while it reduced the yield of the $25^{\circ} \mathrm{C}$ group. The stimulatory mechanism of $\mathrm{Cd}$ addition in the $55^{\circ} \mathrm{C}$ group was recognized as higher COD during the peak period, the efficient transformation of hydrolytic products into VFAs, especially acetic acid, 
and higher activities of cellulase and coenzyme $\mathrm{F}_{420}$. Moreover, a high temperature of $55^{\circ} \mathrm{C}$ promoted the transfer of more $\mathrm{Cd}$ from liquor to solid substrate at the beginning of the digestion stage, thus accelerating the digestion start-up. At temperatures of $45^{\circ} \mathrm{C}, 35^{\circ} \mathrm{C}$, and $25^{\circ} \mathrm{C}$, there was no significant difference in cellulase and coenzyme $\mathrm{F}_{420}$ activity between the $\mathrm{Cd}$-added and no $\mathrm{Cd}$-added group. In conclusion, a temperature of $55^{\circ} \mathrm{C}$ is suggested for enhancing the degradation of biowaste in anaerobic conditions and in the presence of $\mathrm{Cd}$.

Supplementary Materials: The following are available online at http://www.mdpi.com/1996-1073/12/12/2367/s1: Figure S1. CH4 contents under $\mathrm{Cd}$ stress with digestion temperatures of $55^{\circ} \mathrm{C}, 45^{\circ} \mathrm{C}, 35^{\circ} \mathrm{C}$, and $25^{\circ} \mathrm{C}$; Figure S2: Volatile fatty acids (VFAs) ratio of the Cd-added group to no Cd-added group with digestion temperatures of 55 ${ }^{\circ} \mathrm{C}(\mathbf{a}), 45^{\circ} \mathrm{C}(\mathbf{b}), 35^{\circ} \mathrm{C}(\mathbf{c})$, and $25^{\circ} \mathrm{C}(\mathbf{d})$. The blue dash line indicates a ratio of 1, i.e., the same amount of VFAs in the Cd-added and no Cd-added groups.

Author Contributions: Conceptualization, Y.T. and H.Z.; methodology, Y.T., Y.L., S.L., and X.M.; software, Y.T., Y.L., and S.L.; validation, all authors; formal analysis, Y.T. and S.L.; investigation, Y.T. and X.M.; resources, H.Z. and H.H.; data curation, Y.T.; writing—original draft preparation, Y.T.; writing—review and editing, Y.T.; visualization, Y.T., Y.L., and S.L.; supervision, H.Z.; project administration, Y.T. and H.Z.; funding acquisition, H.Z. and H.H.

Funding: This research was funded by the Major Science and Technology Program for Water Pollution Control and Treatment (grant numbers 2015ZX07204-007 and 2017ZX07101-003), and the Fundamental Research Funds for the Central Universities (grant number 2018MS051).

Acknowledgments: We acknowledge Beijing Dairy Cattle Center for kindly supplying cow dung for the experiments. We thank Edmond Sanganyado for helping polish the language of the revised manuscript.

Conflicts of Interest: The authors declare no conflict of interest.

\section{References}

1. Uma, S.; Thalla, A.K.; Devatha, C.P. Co-digestion of food waste and switchgrass for biogas potential: Effects of process parameters. Waste Biomass Valorization 2018, 1-13. [CrossRef]

2. Fernandes, K.D.; Cañote, S.J.B.; Ribeiro, E.M.; Thiago Filho, G.L.; Fonseca, A.L. Can we use Cd-contaminated macrophytes for biogas production? Environ. Sci. Pollut. Res. 2018, 1-11. [CrossRef] [PubMed]

3. Bhui, I.; Mathew, A.K.; Chaudhury, S.; Balachandran, S. Influence of volatile fatty acids in different inoculum to substrate ratio and enhancement of biogas production using water hyacinth and salvinia. Bioresour. Technol. 2018, 270, 409-415. [CrossRef] [PubMed]

4. Manyiloh, C.E.; Mamphweli, S.N.; Meyer, E.L.; Okoh, A.I.; Makaka, G.; Simon, M. Microbial anaerobic digestion (bio-digesters) as an approach to the decontamination of animal wastes in pollution control and the generation of renewable energy. Int. J. Environ. Res. Public Health 2013, 10, 4390-4417. [CrossRef] [PubMed]

5. Jain, S.K.; Gujral, G.S.; Jha, N.K.; Vasudevan, P. Production of biogas from Azolla pinnata R.Br and Lemna minor L.: Effect of heavy metal contamination. Bioresour. Technol. 1992, 41, 273-277. [CrossRef]

6. Lin, C.-Y. Effect of heavy metals on volatile fatty acid degradation in anaerobic digestion. Water Res. 1992, 26, 177-183. [CrossRef]

7. Šotnar, M.; Mareček, J.; Máchal, P.; Koutný, T.; Geršl, M.; Krčálová, E.; Korenko, M. Biogas production of phytoremediation plants contaminated with cadmium. НаучниТрудовеРусенския Университет 2014, 53,174 .

8. Zhang, H.; Tian, Y.; Wang, L.; Zhang, L.; Dai, L. Ecophysiological characteristics and biogas production of cadmium-contaminated crops. Bioresour. Technol. 2013, 146, 628-636. [CrossRef]

9. Bo, M.; Florczak, I.; Zdanowska, P.; Wojdalski, J. An analysis of metal concentrations in food wastes for biogas production. Renew. Energy 2015, 77, 467-472.

10. Abdel-shafy, H.I.; Mansour, M.S.M. Biogas production as affected by heavy metals in the anaerobic digestion of sludge. Egypt. J. Pet. 2014, 23, 409-417. [CrossRef]

11. Keshri, J.; Mankazana, B.B.J.; Momba, M.N.B. Profile of bacterial communities in South African mine-water samples using Illumina next-generation sequencing platform. Appl. Microbiol. Biotechnol. 2015, 99, 3233-3242. [CrossRef] [PubMed]

12. Matheri, A.N.; Belaid, M.; Seodigeng, T.; CatherineNgila, J. The role of trace elements on anaerobic co-digestion in biogas production. In Proceedings of the World Congress on Engineering, London, UK, 29 June-1 July 2016. 
13. Yu, H.Q.; Fang, H.H.P. Inhibition by chromium and cadmium of anaerobic acidogenesis. Water Sci. Technol. 2001, 43, 267-274. [CrossRef] [PubMed]

14. Tian, Y.; Zhang, H. Producing biogas from agricultural residues generated during phytoremediation process: Possibility, threshold, and challenges. Int. J. Green Energy 2016, 13, 1556-1563. [CrossRef]

15. Lira-Silva, E.; Santiago-Martínez, M.G.; Hernández-Juárez, V.; García-Contreras, R.; Moreno-Sánchez, R.; Jasso-Chávez, R. Activation of methanogenesis by cadmium in the marine archaeon Methanosarcina acetivorans. PLoS ONE 2012, 7, e48779. [CrossRef] [PubMed]

16. Zhang, H.; Han, X.; Tian, Y.; Li, Y.; Yang, K.; Hao, H.; Chai, Y.; Xu, X. Process analysis of anaerobic fermentation of Phragmites australis straw and cow dung exposing to elevated chromium (VI) concentrations. J. Environ. Manag. 2018, 224, 414-424. [CrossRef] [PubMed]

17. Hao, H.; Tian, Y.; Zhang, H.; Chai, Y. Copper stressed anaerobic fermentation: Biogas properties, process stability, biodegradation and enzyme responses. Biodegradation 2017, 28, 369-381. [CrossRef]

18. Tian, Y.; Zhang, H.; Chai, Y.; Wang, L.; Mi, X.; Zhang, L.; Ware, M.A. Biogas properties and enzymatic analysis during anaerobic fermentation of Phragmites australis straw and cow dung: Influence of nickel chloride supplement. Biodegradation 2017, 28, 15-25. [CrossRef]

19. Tian, Y.; Zhang, H.; Mi, X.; Wang, L.; Zhang, L.; Ai, Y. Research on anaerobic digestion of corn stover enhanced by dilute acid pretreatment: Mechanism study and potential utilization in practical application. J. Renew. Sustain. Energy 2016, 8, 023103. [CrossRef]

20. Su, Y. Biogas Fermentation Detection Technology; Metallurgical Industry Press: Beijing, China, 2011.

21. Chen, Y.; Cheng, J.J.; Creamer, K.S. Inhibition of anaerobic digestion process: A review. Bioresour. Technol. 2008, 99, 4044-4064. [CrossRef]

22. Leyva-Ramos, R.; Bernal-Jacome, L.A.; Acosta-Rodriguez, I. Adsorption of cadmium (II) from aqueous solution on natural and oxidized corncob. Sep. Purif. Technol. 2005, 45, 41-49. [CrossRef]

23. Zhu, Z.; Cheng, G.; Zhu, Y.; Zeng, H.; Wei, R.; Wei, C. The effects of different anaerobic fermentation temperature on biogas fermentation of swine manure. In Proceedings of the 2011 International Conference on Computer Distributed Control and Intelligent Environmental Monitoring, Changsha, China, 19 February 2011.

24. Jayaweera, M.W.; Dilhani, J.A.; Kularatne, R.K.; Wijeyekoon, S.L. Biogas production from water hyacinth (Eichhornia crassipes (Mart.) Solms) grown under different nitrogen concentrations. J. Environ. Sci. Health Part A Toxic/Hazardous Subst. Environ. Eng. 2007, 42, 925-932. [CrossRef] [PubMed]

25. Amarneh, F.F.K. Quantitative and Qualitative Assessment of Macronutrients and Micronutrients of Digestate from Biogas Units under Different Feedstock Loadings. Master's Thesis, An-Najah National University, Bloomington, IN, USA, 2014.

26. Yu, H.Q.; Fang, H.H.P.; Tay, J.H. Effects of $\mathrm{Fe}^{2+}$ on sludge granulation in upflow anaerobic sludge blanket reactors. Water Sci. Technol. 2000, 41, 199-206. [CrossRef]

27. Chakraborty, N.; Chatterjee, M.; Sarkar, G.M.; Lahiri, S.C. Inhibitory effects of the divalent metal ions on biomethanation by iolated mesophilic methanogen in AC21 medium in presence or absence of juices from water hyacinth. Bioenergy Res. 2010, 3, 314-320. [CrossRef]

28. Zhang, H.; Tian, Y.; Wang, L.; Mi, X.; Chai, Y. Effect of ferrous chloride on biogas production and enzymatic activities during anaerobic fermentation of cow dung and Phragmites straw. Biodegradation 2016, 27, 69-82. [CrossRef] [PubMed]

29. Harper, S.R.; Pohland, F.G. Recent developments in hydrogen management during anaerobic biological wastewater treatment. Biotechnol. Bioeng. 1986, 28, 585-602. [CrossRef] [PubMed]

30. Nettmann, E.; Bergmann, I.; Pramschu, S.; Mundt, K.; Plogsties, V.; Herrmann, C.; Klocke, M. Polyphasic analyses of methanogenic archaeal communities in agricultural biogas plants. Appl. Environ. Microbiol. 2010, 76, 2540-2548. [CrossRef] [PubMed]

31. Tripp, B.C.; Rd, B.C.; Cruz, F.; Krebs, C.; Ferry, J.G. A role for iron in an ancient carbonic anhydrase. J. Biol. Chem. 2004, 279, 6683. [CrossRef] [PubMed]

(C) 2019 by the authors. Licensee MDPI, Basel, Switzerland. This article is an open access article distributed under the terms and conditions of the Creative Commons Attribution (CC BY) license (http://creativecommons.org/licenses/by/4.0/). 